\title{
Application Of The Problem Based Learning Model To Improve Communicating Skill In Elementary School Students
}

\section{Fajar Puji Hardono}

Universitas Sebelas Maret

fajarpujihardono.ppg@student.uns.ac.id

\section{Article History}

received 30/4/2021

revised 30/5/2021

accepted 30/6/2021

\begin{abstract}
This study aims to improve communicating skill in fourth grade students of State Elementary School of 01 Papahan Karanganyar in academic year 2020/ 2021 through science learning with online system use Zoom Meeting by applying the model of Problem Based Learning (PBL). This form of research is a classroom action research (PTK) conducted in three cycles. Each cycle consists of two meetings, each meeting starting from the planning, implementation, observation, and reflection. The subjects research are teacher and fourth grade students of State Elementary School of 01 Papahan Karanganyar in academic year 2020/2021 a total of 33 students. The data source comes from teachers, students and some documents. Technical data used are observation, interview and document review. The validity technique used is content validity. Data analysis techniques used data, data reduction, data presentation and withdrawal. The result of the research shows that Problem Based Learning (PBL) model can improve communicating skill in fourth grade students of State Elementary School of 01 Papahan Karanganyar in academic year 2020/ 2021.
\end{abstract}

Keywords: Communicating skill, Problem Based Learning, Elementary School

\begin{abstract}
Abstrak
Penelitian ini bertujuan untuk meningkatkan keterampilan mengomunikasikan pada siswa kelas IV SD Negeri 01 Papahan Karanganyar tahun ajaran 2020/ 2021 melalui pembelajaran IPA secara daring menggunakan Zoom Meeting dengan menerapkan model pembelajaran Problem Based Learning (PBL). Bentuk penelitian ini adalah penelitian tindakan kelas (PTK) yang dilaksanakan dalam tiga siklus. Masing-masing siklus terdiri dari dua pertemuan, setiap pertemuan dimulai dari tahap perencanaan, pelaksanaan, observasi, dan refleksi. Subjek penelitian guru dan siswa kelas IV SD Negeri 01 Papahan Karanganyar tahun ajaran 2020/ 2021 sejumlah 33 siswa. Sumber data berasal dari guru, siswa dan beberapa dokumen. Teknik pengumpulan data yang digunakan adalah observasi, wawancara dan kajian dokumen. Teknik uji validitas yang digunakan adalah validitas isi. Teknik analisis data yang digunakan meliputi pengumpulan data, reduksi data, penyajian data dan penarikan kesimpulan. Hasil penelitian menunjukkan bahwa model pembelajaran Problem Based Learning (PBL) dapat meningkatkan keterampilan mengomunikasikan pada siswa kelas IV SD Negeri 01 Papahan Karanganyar tahun ajaran 2020/ 2021.
\end{abstract}

Kata kunci: Keterampilan mengomunikasikan, Problem Based Learning, Sekolah Dasar 


\section{PENDAHULUAN}

Pendidikan yang diharapkan di abad 21 ini menekankan bahwa pendidikan harus mampu menghasilkan sumber daya manusia yang memiliki kompetensi yang saling terintegrasi diantaranya kompetensi kognitif (pengetahuan), kompetensi afektif (sikap) dan kompetensi keterampilan. Pada pelaksanaan aktualisasi kurikulum 2013 secara menyeluruh, tentunya diperlukan suatu cara agar bisa memperlancar dalam proses aktualisasi, salah satunya adalah pendekatan saintifik. Penerapan pendekatan saintifik dalam pembelajaran dapat membangun dan mengintegrasikan kompetensi kognitif (pengetahuan), kompetensi afektif (sikap) dan kompetensi keterampilan. Hal tersebut diperkuat oleh pendapat Majid dan Rochman yang menyatakan bahwa "Penguatan proses pembelajaran dilakukan melalui pendekatan saintifik, yaitu pembelajaran yang mendorong peserta didik lebih mampu dalam mengamati, menanya, mencoba/ mengumpulkan data, mengasosiasi/ menalar, dan mengomunikasikan" (2014: 1-2). Berdasarkan uraian di atas dapat disimpulkan bahwa implementasi kurikulum 2013 dapat menjawab harapan pendidikan di abad 21 ini dengan menghasilkan lulusan yang bisa memiliki 3 kompetensi dasar secara terintegratif.

Implementasi pembelajaran pada kurikulum 2013 dengan pendekatan saintifik dirancang sedemikian rupa agar siswa aktif mengonstruk konsep melalui keterampilan proses dengan tahapan-tahapan yakni mengamati, menanya, mengumpulkan informasi, mengasosiasi/ menganalisis, dan mengomunikasikan (Hosnan, 2014: 34). Pelajaran yang memuat seluruh tahap dalam pendekatan saintifik adalah mata pelajaran IImu Pengetahuan Alam (IPA). Keterampilan proses IPA luas dan menyeluruh, sehingga perlu difokuskan pada keterampilan mengomunikasikan. Keterampilan mengomunikasikan juga dibatasi pada keterampilan mengomunikasikan secara tertulis. Komunikasi merupakan kemampuan untuk menyampaikan hasil pengamatan atau pengetahuan yang dimiliki kepada orang lain, baik secara lisan maupun tulisan (Bundu, 2006: 26). Agar dapat mengembangkan keterampilan mengomunikasikan, siswa perlu diberikan kesempatan untuk mempraktikkan kegiatan komunikasi secara langsung. Kegiatan didukung dengan beberapa fasilitas penunjang agar siswa bisa lebih tertarik dan bisa melakukan kegiatan dengan maksimal.

Namun kenyataan yang terjadi di lapangan, siswa belum terampil dalam melakukan keterampilan mengomunikasikan, hal ini dibuktikan dari data yang diperoleh menunjukkan keterampilan mengomunikasikan siswa kelas IV SD Negeri 01 Papahan Karanganyar tahun ajaran 2020/ 2021 masih kurang terampil. Dari 33 siswa terdapat 20 siswa yang masih dalam kategori kurang terampil dengan persentase $60,61 \%$. Masalah kurang terampilnya siswa perlu segera diatasi agar keterampilan mengomunikasikan bisa terimplementasi secara maksimal. Guru perlu menggunakan model pembelajaran yang efektif, belum pernah diterapkan sebelumnya, menarik minat dan perhatian belajar siswa, dan melibatkan siswa secara aktif. Model pembelajaran yang memiliki karakteristik mendukung keterampilan mengomunikasikan adalah model pembelajaran Problem Based Learning (PBL).

Menurut Shoimin (2014: 129), model pembelajaran Problem Based Learning (PBL) adalah model pembelajaran yang dapat melatih dan mengembangkan kemampuan untuk menyelesaikan masalah yang berorientasi pada masalah autentik dari kehidupan aktual siswa. Pernyataan tersebut dijelaskan lebih lanjut oleh Shoimin, yang menyatakan "PBL" dapat meningkatkan aktivitas ilmiah pada siswa melalui kerja kelompok. Pada pelaksanaan $\mathrm{PBL}$, rasa ingin tahu siswa akan bangkit sehingga membuat mereka tertarik untuk menyelidiki (Sugiyanto, 2009:157). Selian itu menurut Shoimin "Penerapan PBL memiliki kelebihan salah satunya adalah siswa memiliki kemampuan untuk melakukan komunikasi ilmiah dalam kegiatan diskusi atau presentasi hasil pekerjaan mereka". Kelebihan tersebut memfasilitasi keterampilan mengomunikasikan secara tertulis, karena dilaksanakan kegiatan praktikum dan selanjutnya dilakukan komunikasi secara ilmiah. 
Permendikbud No. 22 tahun 2016 menerangkan bahwa keterampilan dapat diperoleh melalui kegitan mengamati, menanya, mencoba, menalar, menyaji, dan mencipta. Untuk mewujudkan keterampilan tersebut perlu melakukan pembelajaran yang menerapkan modus belajar berbasis penyingkapan/ penelitian dan pembelajaran yang menghasilkan karya berbasis pemecahan masalah.Pemilihan model pembelajaran berbasis masalah sebagai solusi atas permasalahan yang dialami siswa kelas IV SD Negeri 01 Papahan Karanganyar didasari alasan bahwa model pembelajaran berbasis masalah dapat mengarahkan siswa untuk melakukan keterampilan mengomunikasikan. Siswa secara aktif dapat merasakan dan mempertanyakan secara mendalam keberadaan masalah dalam pembelajaran. Berdasarkan permasalahan yang terjadi dalam pembelajaran, siswa dapat diarahkan secara aktif dan mampu melakukan kegiatan observasi dan mengomunikasikan hasil belajarnya secara tertulis dengan lebih baik. Keaktifan siswa dan pengalaman langsung seperti kegiatan praktikum dalam mata pelajaran IPA akan memberikan kebermaknaan dalam kegiatan belajar siswa. Maka dari itu siswa menjadi lebih mudah melakukan kegiatan mengomunikasikan hasil belajarnya di dalam pembelajaran.

\section{METODE}

Penelitian ini dilaksanakan di SD Negeri 01 Papahan Karanganyar Karanganyar semester II tahun ajaran 2020/ 2021. Penelitian ini dilaksanakan dalam tiga siklus, setiap siklus terdiri dari empat tahap yaitu: 1) perencanaan; 2) pelaksanaan; 3) observasi; dan 4) refleksi. Subjek penelitian ini adalah guru dan siswa kelas IV SD Negeri 01 Papahan Karanganyar Karanganyar tahun ajaran 2020/ 2021 sejumlah 33 siswa, sumber data berasal dari guru, siswa dan beberapa dokumen. Teknik pengumpulan data yang digunakan adalah observasi, wawancara dan kajian dokumen. Teknik uji validitas yang digunakan adalah validitas isi. Teknik analisis data yang digunakan meliputi: 1) pengumpulan data; 2) reduksi data; 3) penyajian data; dan 4) penarikan kesimpulan.

\section{HASIL DAN PEMBAHASAN}

Sebelum melaksanakan tindakan terlebih dahulu diadakan pratindakan yang terdiri dari observasi, dan wawancara terhadap pembelajaran IPA secara daring menggunakan Zoom Meeting. Dari hasil pratindakan menunjukkan mayoritas siswa masih termasuk kategori kurang terampil dalam keterampilan mengomunikasikan. Data frekuensi nilai keterampilan mengomunikasikan pratindakan dapat dilihat pada tabel 1 berikut:

Tabel 1. Keterampilan Mengomunikasikan Pratindakan

\begin{tabular}{lccc}
\hline \multicolumn{1}{c}{ Kategori } & Interval & Jumlah Siswa & Persentase \\
\hline Tidak terampil & $<50$ & 8 & $24,24 \%$ \\
Kurang terampil & $50-74$ & 12 & $36,36 \%$ \\
Cukup terampil & $75-84$ & 11 & $33,33 \%$ \\
Terampil & $85-89$ & 2 & $6,06 \%$ \\
\hline
\end{tabular}

Berdasarkan pembahasan nilai keterampilan mengomunikasikan dapat diketahui hasil dari pratindakan. Pada keterampilan mengomunikasikan yang tergolong terampil sejumlah 2 siswa, cukup terampil sejumlah 11 siswa, kurang terampil 12 siswa dan tidak terampil sejumlah 8 siswa. Selanjutnya dilakukan diskusi dengan guru kelas IV SD Negeri 01 Papahan Karanganyar untuk mendapatkan pemecahan masalah agar keterampilan mengomunikasikan dapat meningkat.

Sebelum dilaksanakan tindakan siklus I terlebih dahulu merencanakan pembelajaran dengan menerapkan model pembelajaran Problem Based Learning. Setelah diadakan tindakan dengan menerapkan model ini, diperoleh nilai keterampilan mengomunikasikan belum mencapai indikator kinerja penelitian namun untuk rata-rata 
nilai sudah mengalami peningkatan. Data nilai keterampilan mengomunikasikan dapat dilihat pada tabel 2 berikut:

Tabel 2. Keterampilan Mengomunikasikan Siklus I

\begin{tabular}{lccc}
\multicolumn{1}{c}{ Kategori } & Interval & Jumlah Siswa & Persentase \\
\hline Tidak terampil & $<50$ & 3 & $9,09 \%$ \\
Kurang terampil & $50-74$ & 14 & $42,43 \%$ \\
Cukup terampil & $75-84$ & 12 & $36,36 \%$ \\
Terampil & $85-89$ & 4 & $12,12 \%$ \\
\hline
\end{tabular}

Berdasarkan tabel diatas dapat diketahui peningkatan ketuntasan klasikal dan nilai rata-rata kelas dari pratindakan, pada siklus I siswa yang sudah mencapai indikator penelitian cukup terampil $(\geq 75)$ sebesar $48,48 \%$. Namun peningkatan pada siklus I ini belum dapat mencapai indikator kinerja yang telah ditetapkan. Indikator kinerja ditentukan sebesar $85 \%$ siswa cukup terampil $(\geq 75)$. Sedangkan hasil yang dicapai pada siklus I belum mencapainya. Oleh karena itu peneliti merencanakan lagi untuk melakukan siklus berikutnya.

Beberapa hal perlu direfleksikan dari pelaksanaan siklus I untuk memperbaiki pelaksanaan siklus berikutnya, semua aspek keterampilan mengomunikasikan secara tertulis yang harus ditingkatkan pada siklus II, perlu dilakukan bimbingan agar siswa bisa menulisakan judul dengan menarik, pada saat menjelaskan hasil laporan guru harus berkeliling sehingga apabila siswa bingung saat membuat penjelasan pada laporan bisa langsung diberi arahan. Pada aspek menuliskan laporan juga harus dipantau agar apa yang ditulis itu mudah dipahami, sesuai konteks dan bisa mudah dipahami. Aspek ejaan juga perlu dilakukan perbaikan dengan menerangkan terlebih dahulu kepada siswa sehingga saat pembuatan laporan selanjutnya ejaannya sudah tepat. Selain ejaan juga perlu dilakukan perbaikan pada pemilihan kata dengan memberikan masukan kata-kata yang biasa digunakan sehari-hari sehingga akan mudah untuk menyampaikan pada suatu laporan. Pada aspek menuliskan informasi juga harus ditekankan lagi agar laporannya bisa komplit dan artinya jelas. Sedangkan kerapian tulisan juga harus diperbaiki, misalya dilarang melakukan kesalahan saat menulis, dilarang menggunakan tipex sehingga secara otomatis siswa akan terbiasa menuliskan dengan rapi.

Berdasarkan kekurangan yang terjadi pada siklus I maka saya dan guru kelas berusaha merencanakan ulang pembelajaran IPA secara daring menggunakan Zoom Meeting dengan menerapkan model Problem Based Learning pada siklus II. Setelah diadakan tindakan pada siklus II dengan menerapkan model ini, diperoleh nilai keterampilan mengomunikasikan juga belum mencapai indikator kinerja penelitian. Data nilai keterampilan mengomunikasikan dapat dilihat pada tabel 3 berikut:

Tabel 3. Keterampilan Mengomunikasikan Siklus II

\begin{tabular}{lccc}
\multicolumn{1}{c}{ Kategori } & Interval & Jumlah Siswa & Persentase \\
\hline Tidak terampil & $<50$ & 3 & $9,09 \%$ \\
Kurang terampil & $50-74$ & 14 & $42,43 \%$ \\
Cukup terampil & $75-84$ & 12 & $36,36 \%$ \\
Terampil & $85-89$ & 4 & $12,12 \%$ \\
\hline
\end{tabular}

Berdasarkan tabel diatas dapat diketahui peningkatan ketuntasan klasikal dan nilai rata-rata kelas dari pelaksanaan siklus I, pada siklus II siswa yang sudah mencapai indikator penelitian cukup terampil $(\geq 75)$ sebesar $81,81 \%$. Pada keterampilan mengomunikasikan belum mencapai indikator kinerja penelitian. Oleh karena itu peneliti merencanakan lagi untuk melakukan siklus berikutnya. 
Beberapa hal perlu direfleksikan dari pelaksanaan siklus I untuk memperbaiki pelaksanaan siklus berikutnya. Aspek penulisan judul sudah baik dan perlu diberi penguatan agar selalu membuat judul yang sesuai indikator. Aspek menjelaskan siswa harus dibimbing lagi agar isi yang dijelaskan mencakup semua informasi yang dipelajari. Aspek menuliskan harus selalu dikontrol agar apa yang ditulis siswa bisa sesuai indikator yang diharapkan. Aspek ejaan masih perlu bimbingan lebih intens. Aspek menggunakan kata juga harus diberitahu dan diarahkan agar menggunakan kata yang efektif dan mudah dipahami. Pada aspek penulisan informasi tambahan harus dibiasakan menulis semua hal penting saat pembelajaran sehingga isinya yang ditulis lebih lengkap. Aspek kerapian tulisan, siswa harus dibiasakan menulis rapi tanpa coretan.

Berdasarkan kekurangan yang terjadi pada siklus II maka saya dan guru kelas masih berusaha merencanakan ulang pembelajaran IPA secara daring menggunakan Zoom Meeting dengan menerapkan model Problem Based Learning pada siklus yang ke III. Setelah diadakan tindakan pada siklus III dengan menerapkan model ini, diperoleh nilai keterampilan mengomunikasikan sudah mencapai indikator kinerja penelitian. Data nilai keterampilan mengomunikasikan dapat dilihat pada tabel 4 berikut:

Tabel 4. Keterampilan Mengomunikasikan Siklus III

\begin{tabular}{lccc}
\hline \multicolumn{1}{c}{ Kategori } & Interval & Jumlah Siswa & Persentase \\
\hline Tidak terampil & $<50$ & 1 & $3,03 \%$ \\
Kurang terampil & $50-74$ & 3 & $9,09 \%$ \\
Cukup terampil & $75-84$ & 16 & $48,49 \%$ \\
Terampil & $85-89$ & 13 & $39,39 \%$ \\
\hline
\end{tabular}

Tabel 4 menunjukkan siswa yang sudah cukup terampil sejumlah 3 siswa atau $9,09 \%$, selanjutnya yang terampil sejumlah 16 siswa atau $48,49 \%$, dan siswa yang sangat terampil sejumlah 13 siswa atau 39,39\%. Dengan demikian pada keterampilan mengomunikasikan juga sudah melampaui indi- kator kinerja penelitian sebesar $96,96 \%$.

Hasil analisis penelitian tindakan kelas ini menunjukkan bahwa pembelajaran IPA secara daring menggunakan Zoom Meeting yang menerapakan model Problem Based Learning (PBL) dapat meningkatkan keterampilan mengomunikasikan pada siswa kelas IV SD Negeri 01 Papahan Karanganyar tahun ajaran 2020/ 2021. Hal tersebut dapat dibuktikan dengan melihat peningkatan keterampilan mengomunikasikan dari setiap aspek indikatornya yang mengalami kenaikan mulai siklus I, siklus II dan siklus III.

Menurut Shoimin (2014: 129), model pembelajaran Problem Based Learning (PBL) adalah model pembelajaran yang dapat melatih dan mengembangkan kemampuan untuk menyelesaikan masalah yang berorientasi pada masalah autentik dari kehidupan aktual siswa. Menurut Suyadi (2013: 137-139) terdapat enam langkah untuk dapat menerapkan PBL dengan baik, diantaranya: (1) Menyadari Adanya Masalah, (2) Merumuskan Masalah, (3) Merumuskan Hipotesis, (4) Mengumpulkan Data, (5) Menguji Hipotesis, (6) Menentukan Pilihan Penyelesaian.

Penerapan PBL memiliki kelebihan salah satunya adalah siswa memiliki kemampuan untuk melakukan komunikasi ilmiah dalam kegiatan diskusi atau presentasi hasil pekerjaan mereka. Pernyataan tersebut tentu sesuai dengan keterampilan mengomunikasikan secara tertulis, karena sudah pasti dilaksanakan kegiatan praktikum dan selanjutnya dilakukan komunikasi secara ilmiah. Selama siklus I, siklus II dan siklus III, pembelajaran IPA secara daring menggunakan Zoom Meeting dilaksanakan dengan model pembelajaran PBL dan hasilnya memperlihatkan peningkatan keterampilan mengomunikasikan pada setiap siklus. Berpijak pada hasil pengolahan data, peningkatan yang terjadi pada keterampilan mengomunikasikan pada siswa kelas IV SD 
Negeri 01 Papahan Karanganyar melalui penerapan model pembelajaran Problem Based Learning (PBL) mengalami peningkatan yang berkelanjutan. Peningkatan ini terjadi karena adanya tindakan secara berkelanjutan pada setiap pertemuan guna memperbaiki dan menyempurnakan kekurangan yang terjadi sebelumnya. Peran guru sebagai fasilitator, pembimbing, dan membantu siswa dalam pembelajaran adalah kunci keberhasilan mencapai tujuan pembelajaran.

Model PBL sendiri memiliki beberapa keunggulan. Menurut Shoimin (2014: 132) Menyebutkan beberapa kelebihan model pembelajaran PBL diantaranya: (1) Pemecahan masalah merupakan teknik yang cukup bagus untuk lebih memahami isi pelajaran, (2) Pemecahan masalah dapat menantang kemampuan siswa sehingga memberikan keleluasaan untuk menentukan pengetahuan baru bagi siswa, (3) Pemecahan masalah dapat meningkatkan aktivitas pembelajaran siswa (4) Pemecahan masalah dapat membantu siswa bagaimana mentransfer pengetahuan mereka untuk memahami masalah dalam kehidupan nyata (5) Pemecahan masalah dapat membantu siswa untuk mengembangkan pengetahuan barunya dan bertanggung jawab dalam pembelajaran yang dilakukan (6) Siswa mampu memecahkan masalah dengan suasana pembelajaran yang aktif dan menyenangkan, (7) Pemecahan masalah dapat mengembangkan kemampuan siswa untuk berpikir kritis dan mengembangkan kemampuan mereka punya beradaptasi dengan pengetahuan baru, (8) Pemecahan masalah dapat memberikan kesempatan pada siswa untuk mengaplikasikan pengetahuan yang mereka miliki dalam dunia nyata.

Berdasarkan hasil analisis data, model PBL tidak hanya meningkatakan keterampilan mengomunikasikan tetapi juga terjadi peningkatan pada aktivitas siswa. Peningkatan ini dibuktikan dengan sikap siswa saat melaksanakan pembelajaran IPA secara daring menggunakan Zoom Meeting serta menggunakan model PBL. Siswa sangat antusias dalam kegiatan pembelajaran dan mampu melaksanakan tugas dari guru dengan baik. Aktivitas ini dimulai dari siswa yang belum bisa melakukan kegiatan pengamatan dan mengomunikasikan dengan baik, tetapi setelah para siswa bersungguh-sungguh akhirnya menjadi terbiasa dan lama kelamaan 32 siswa dari 33 siswa sudah bisa dikatakan tuntas dari keterampilan mengomunikasikan.

Pada saat pelaksanaan setiap siklusnya juga ditemui permasalahan. Pada siklus I masih terjadi kurang aktif saat pembelajaran IPA secara daring menggunakan Zoom Meeting, guru juga belum terlalu siap menghadapi karakter murid yang baru di kenal. Selain itu, siswa jarang melakukan tanya jawab sehingga belum bisa melaksanakan keterampilan mengomunikasikan dengan baik. Pada tahap mengomunikasikan siswa belum terbiasa membuat laporan sehingga hanya membuat laporan yang ala kadarnya tanpa menerapkan aturan yang ada. Adapun upaya yang dilaksanakan untuk mengatasi masalah tersebut misalnya guru belajar mengenal karakter murid dengan bertanya pada guru kelas pada ruang maya Zoom meeting. Selanjutnya selalu memberi motivasi dan menarik perhatian siswa dalam pembelajaran dengan menampilkan video pembelajaran yang meanarik. Guru harus sabar dan selalu membimbing kegiatan mengomunikasikan siswa. Kekurangan yang terjadi pada siklus I diperbaiki pada siklus II dan siklus III yakni dengan memaksimalkan media pembelajaran berupa video, memberikan pembimbingan dengan cara japri melalui WhatsApp, mengarahkan alat di rumah yang bisa membantu proses kegiatan mengomunikasikan.

Berpijak pada data yang diperoleh serta pembahasan di atas disimpulkan penerapan model pembelajaran Problem Based Learning (PBL) terbukti dapat meningkatkan nilai keterampilan mengomunikasikan pada siswa kelas IV SD Negeri 01 Papahan Karanganyar tahun ajaran 2020/ 2021. Selain itu PBL juga bisa membuat guru menjadi lebih kreatif dan maju karena bisa menerapkan model pembelajaran yang lebih menarik dan menyenangkan, lebih dari itu ternyata proses pembelajaran daring di kelas maya juga menjadi lebih baik dan siswa menjadi lebih kritis, aktif, dan bisa melaksanakan keterampilan mengomunikasikan dengan maksimal. 


\section{SIMPULAN}

Berdasarkan hasil Penelitian Tindakan Kelas (PTK) yang telah dilakukan sebanyak tiga siklus pada pembelajaran IPA secara daring menggunakan Zoom Meeting dengan menerapkan model pembelajaran Problem Based Learning (PBL) dapat meningkatkan keterampilan mengomunikasikan pada siswa kelas IV SD Negeri 01 Papahan Karanganyar tahun ajaran 2020/ 2021. Hal ini ditunjukkan dengan meningkatnya nilai keterampilan mengomunikasikan mencapai 96,96\% atau 32 siswa dari 33 siswa sudah sudah cukup terampil (75-84). Walaupun indikator kinerja penelitian memberi batas minimal cukup terampil, ternyata pencapaian justru melampaui. Pada pelaksanaan siklus III, dari 32 siswa yang bisa mencapai indikator penelitian mayoritas siswa SD Negeri 01 Papahan Karanganyar tahun ajaran 2020/ 2021 sudah mencapai kategori sangat terampil (>90) baik keterampilan mengamati dan keterampilan mengomunikasikan.

\section{DAFTAR PUSTAKA}

Bundu, P. (2006). Penilaian Keterampilan Proses dan Sikap IImiah dalam Pembelajaran SAINS-SD. Jakarta: Direktorat Jenderal Pendidikan Tinggi.

Hosnan, M. (2014). Pendekatan Saintifik dan Kontekstual dalam Pembelajaran Abad 21. Bogor: Ghalia Indonesia.

Majid, A. \& Chaerul, R. (2014). Pendekatan IImiah dalam Implementasi Kurikulum 2013. Bandung: PT Remaja Rosdakarya.

Permendikbud No. 22 Tahun 2016 Tentang Standar Proses Pendidikan Dasar dan Menengah.

Shoimin, A. (2014). 68 Model Pembelajaran Inovatif dalam Kurikulum 2013. Yogyakarta: Ar-Ruzz Media.

Sugiyanto. (2009). Model-Model Pembelajaran Inovatif. Surakarta: Panitia Sertifikasi Guru Rayon 13 FKIP UNS Surakarta.

Suyadi. (2013). Strategi Pembelajaran Pendidikan Karakter. Bandung: PT Remaja Rosdakarya. 